\title{
【特 集：廃棄物の埋立と環境保全】
}

\section{埋立地浸出水の水量水質問題と準好気性埋立構造}

田中 信 寿*

【要 旨】埋立地浸出水の水量水質制御は困難な技術といえる。わか国におけるこの技術の根幹は, 浸 出水集排水管網と浸出水調整池を適切に設計して埋立地内のすべての污水を速やかに集排水すると共に, 外気を定常的に埋立地内に取り込むことにある。この点について，筆者らの全国市町村埋立地アンケー 卜調查を用いて検討した。その結果，今後一層，準好気性埋立構造の概念を普及すると共に，合理的な 管網や調整池の設計法を開発することが必要であることを示した。

キーワード: 浸出水量, 浸出水質, 準好気性, 浸出水調整池, 浸出水集排水管

1.はじめに

わが国は温帯モンスーン気候帯に属し多雨多湿である。

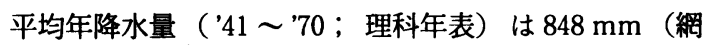
走）から $3,284 \mathrm{~mm}$ （八丈島）に達する一方, 年可能蒸 発量 $E$ （水分供給のよい地表面からの蒸発量）は, 筆者 らの試算によれば表 1 のように $370 \mathrm{~mm}$ (網走) から $1,300 \mathrm{~mm}$ (那覇) であり, いずれの地点であ降水量が

表 1 各気候区におけるペンマン式による可能蒸発量 計算値

\begin{tabular}{|c|c|c|c|}
\hline 気候区 & & & $E[\mathrm{~mm} / \mathrm{y}]$ \\
\hline \multirow[t]{5}{*}{ 日本海型 } & オホーツク海型 & 網走 & 370 \\
\hline & 東北・北海道型 & 札幌 & 472 \\
\hline & & 秋田 & 696 \\
\hline & 北陸・山陰型 & 新潟 & 815 \\
\hline & & 鳥取 & 689 \\
\hline 九 州 型 & & 長崎 & 744 \\
\hline 南 海 型 & & 高知 & 738 \\
\hline 瀬戸内海型 & & 岡山 & 723 \\
\hline \multirow{4}{*}{ 東日本型 } & 東部北海道型 & 釧路 & 393 \\
\hline & 三陸常磐型 & 宮古 & 459 \\
\hline & 東海関東型 & 東京 & 906 \\
\hline & 中央高原型 & 長野 & 645 \\
\hline 沖 縄 型 & & 那覇 & 1328 \\
\hline
\end{tabular}

積雪時には， $E=0$ として計算した。

1988年度の気象データを用いた。

原稿受付 1992.12.7

* 北海道大学工学部衛生工学科 教授

連絡先： $\mathbf{7} 060$ 札幌市北区北 13 条西 8 丁目
蒸発量を上回っている。したがって埋立地への降水量の 半分程度は浸出水となって流出するので, 埋立地におけ る浸出水管理は環境保全上必須の課題である。しかす台 風の襲来や梅雨時には，集中的な大量の降雨に見舞われ るために量的質的に大きく变動する浸出水の制御は極め て困難である。また, 浸出水は廃衰物中の溶解性成分や 微生物分解生成物を溶解するので, その污濁度は高く, その処理は必須である。本稿では, このような浸出水の 水量と水質の制御について, わが国の現状施設の状況を みながら,わが国に特有な準好気性埋立構造の達成とい う観点から考察する。なお，当然のことであるが，ここ で取り扱う問題は一般廃裹物埋立処分場や管理型産業廃 棄物埋立処分場を対象としている。

\section{2. 解説指針による漫出水制御方法の概要}

平成元（1989）年 3 月に刊行された「廃衰物最終処分 場指針解説」"（以下，指針解説という） は 320 頁に及 び, これまでのものに比べ, 飛躍的に前進した内容と なっている。その中で, 浸出水に関係する項目は, 雨水 集排水施設, 浸出水集排水施設, 及び浸出水処理施設の 設計に関連して, 記述されている。また，埋立管理に関 連してモニタリング管理や埋立作業の項目においてあ言 及されている。

浸出水制御の方法は次のように要約される。雨水集排 水施設は, 埋立地内外に降る降水を可能な限り埋立地外 に排除するための施設であり，区画埋立計画の実施とあ いまって浸出水量そのあのを減少させることができる。 
埋立地に侵入した水は，その一部が太陽エネルギーや風 の作用により蒸発するが，廃棄物層内を通過して污濁成 分を溶解した後, 浸出水集排水施設により集排水される。 このとき，どのような埋立構造をとるか，どのようなご み質のもの（ごみ質管理）がどのような埋立方法で埋め 立てされるか（埋立作業内容）によって浸出水の水質が 異なってくる。浸出水の集排水には，しゃ水工や眝留構 造物む一定の役割を果たすが，基本的には集排水管網に よって速やかに集排水することが肝要であり，集排水管 網及びガス抜き管（両管は水とガスを集め排除するとい う同じ機能を持ち, 埋立地に広く配置され，かつそれら が結合されて管網を形成することが重要であると筆者は 考えている）の配置計画が水量水質に重大な影響を与え る。集水された浸出水は浸出水処理施設で地域の環境条 件に合致した放流水質まで処理される。水処理施設の設 計に当たっては水量及び水質の予測が必要であるが，こ れが難しいために比較的て長なプロセスとならざるを得 ない側面をむっている。また，管理面においては季節的 な水量水質変化，長期的な水量水質变化を予測して，浸 出水処理作業計画や異常時対策を立てておく必要がある。

以上のことから，指針解説に述べられている浸出水に よる環境污染防止のための多重安全構造を筆者の考えで 整理すれば，1）環境污染上有害な廃棄物は持ち込まな い（だから管理型処分場），2）降雨水を制御して発生 する浸出水量を可能な限り隇量することで環境への污濁 負荷を減少させる，3）適切な埋立作業を行い，また埋 立廃棄物層内で污濁物を分解処理して浸出水中の污濁物 濃度を減少させることで環境への污濁負荷を減少させる （準好気性構造は BOD, COD, T-N の減少に効果的で ある，４）しゃ水工，浸出水集排水施設及び浸出水処 理施設の機能発揮によって, 浸出水を無害化せずに環境 に放出することはない（特に，集排水管によって速やか に浸出水を排除することによってしゃ水工からの漏水リ スクを減少させる)，5）地下水モニターによって浸出 水漏出による環境污染を監視し, 環境保全上問題があれ ばすぐに対策を行う（幸い，塩素イオンという良好なも ニター物質があるので早期発見ができる)，である。

以上の安全策の中で根幹となる考え方の一つは，a） 埋立地内の污水を速やかに排除することによって浸出水 の地下漏出リスクを減少させると同時に，b）浸出水集 排水管を通して外気を埋立地内に流入させることによっ $\tau$, 水中污濁成分の処理機能をむつ準好気性構造機能を 最大限発揮させることにある。本稿ではこの指針解説の 主要な特徵点が浸出水の水量水質の制御という点でどの ように理解され, 実現されているのかについて, 筆者ら が行った全国アンヶート調查に基づいて考察する。

\section{3. アンケートの内容と検討対象施設の概要}

アンケート（1989 年 9 月発送）は市町村の埋立地の 浸出水量時系列を得るために行ったものでそのデータの 背景を知るために，埋立ごみ質，処分場の形態や集水面 積, 浸出水処理能力, しゃ水工, 浸出水集排水管の構造 と配置，覆土などについて聞き，可能ならば浸出水質測 定デー夕を提供してくれるようにお願いした。なお，水 量水質デー夕は 1988 年度を対象とした。(したがって, 指針解説はその時点の実態を反映しているとは言え，そ の出版以前に計画された施設は必ずしも指針解説の指示 通りに作られているとは言えないのは当然であるが， あ る程度その状況を反映しているのではないかと考え以下 の考察を行った）

280 市町村・組合に送付し，53\% から何等かの回答が あった。この中から, 回答が比較的完備し, しゃ水工が 設置されている施設 64 力所を指針解説の考えに準拠し ていると考え, 本稿の考察の対象とした。その背景とし ては，埋立場所としては山間埋立；48，平地埋立；16 力所, 埋立構造としては回答に従えば（後述するように 準好気性構造が損なわれていると判断されるるのがあ る), 準好気性； 51 , 改良型嫌気性；10, 無回答； 3 力 所, しゃ水工としては, 表面型； 55 , 鉛直型； 9 力所で あった。

なお,これと同様の調查の結果が指針解説にも引用さ れているし，また，より新しい調查"あある。

\section{4. 漫出水集排水施設の機能と構造・配置}

浸出水集排水施設は集排水管と浸出水取水設備, 浸出 水導水設備からなる。集排水管は，底部，法面，堅型集 排水管からなり，わが国が目指す準好気性埋立構造の根 幹的設備である。この設備が, 発生した浸出水を速やか に埋立地内から排除してしゃ水工の負担を軽減すると共 に，空気の導入管として機能するからである。

アンケートから集水管幹線の最大径 $D[\mathrm{~mm}]$ を埋立 地集水面積（計画） $A$ [ha] に対してプロットすると図 1 のようになる（蛇籠 2 力所及び不明を除く）。図中に は浸出水が管の勾配 $T=1 / 100$, マニングの粗度係数 $n$ $=0.01$ で, 管内を中心角 120 度の潤辺で流れるとした とき, 集水面からの浸透強度 $C^{*} I^{*}[\mathrm{~mm} / \mathrm{h}]$ に対して計 算した $A$ 対 $D$ の関係である。（C は浸出係数， $I$ は降雨 強度）

$$
D=1000\left\{C^{*} I^{*} A /(360 \times 0.42695)\right\}^{3 / 8}
$$

また，図中の記号は，有孔管（perforated pipe）と透 


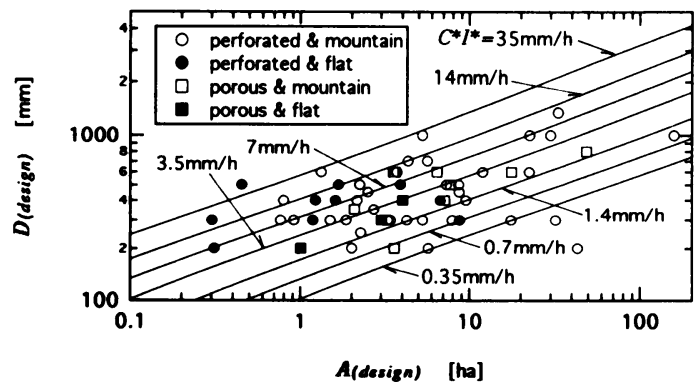

図 1 計画集水面積 $A$ と集排水管最大径 $D$ 関係

水管 (porous pipe), 山間埋立 (mountainous area) と平地埋立（flat area）の各分類組合せで示したもの であるが，傾向は見いだせない。図から $D$ は浸透強度 $C^{*} I^{*}=35 \sim 0.35 \mathrm{~mm} / \mathrm{h}$ 程度に対応する極めて幅広い分 布となっており，十分な排水能力を持っているとできる あのから，速やかな排水を考慮に入れていない（明らか に埋立地内に浸出水が内部眝留 (滞留) すると考えてい る）ものまであり，後者のものは指針解説の考え方に立 脚していない。また, 管の種類については, 有孔管； 45, 透水管；12，不明 7 力所であり（透水管と有孔管の区別 のできていない回答むあった)，集排水管の構造につい ては, 指針解説に示す構造（p. 104 図II-17）が 28 力 所と多いが，しゃ水工上面に水を滞留させることになる 構造が 14 力所，集排水管被覆材の集水面積の小さい構 造も 14 力所と多くみられ, 被覆材を砂で行っているも のも 3 力所あった。指針解説では，管面及び管被覆材の 詰まり，特に微生物やカルシウムスケールによる詰まり を防止する意味から有孔管及び大砕石による被覆を推奖 しているが，以上のように，指針解説が目指している速 やかな排水及び好気性構造機能の発揮（後述）という点 に問題があり，指針解説の考え方の徹底が望まれる。

さらに, 浸出水集排水管の役割の 1 つは, 外気の埋立. 地内への導入による準好気性機能の増進にあるので, こ れの管径はかなり大きくなければならない。指針解説で その役割や管径計算方法が明確に示されていないのは残 念であるが, 最近の研究で, 集排水管の近傍領域で浸出 水中 BOD の除去が起こるという研究 ${ }^{3)}$ や, 大規模なラ イシメータ実験で層底部で BOD 除去や窒素の硝化・脱 窒が起こるという実験的研究 (4) は，このことに関する事 実を提供すると共に，集排水管網設計理論への前進が期 待される。また，このためには，集水管の集水断面に目 詰まりがなく十分な通気面積が確保されると共に, 埋立. 地内における集排水管の管網化及び末端部の大気開放が 必要である（法面集排水管もガスの流動抵抗の小さなむ のであることが必要で，蛇籠などは望ましくない）こと は，指針解説では明確に述べられていないが，図的には
指針解説の図 II-16（p. 99）に示されている。管網化に 関してはアンケートから，竪型集排水管を含めた管網化 が達成できていると思われるものが 24 力所，竪形管は ないが管路網状になっているものが 15 力所と多く，解 説指針に準拠している。しかし，管路配置が不十分なも のが 13 力所もあり，しゃ水工に負担をかけず速やかに 浸出水を排除するという指針解説の考え方に反する。

以上述べたように，準好気性構造を標榜しながら，必 ずしもそれが達成できていない事例が散兒される。

\section{5. 漫出水処理能力と調整設備（池）容量}

浸出水処理施設は浸出水調整設備之水処理設備からな る。埋立地自体のもつ浸出水量・水質低減機能を最大限 に利用しながら, 調整池によって量的質的変動を緩和し つつ, 発生した浸出水のすべてを放流基準まで処理でき る施設を設計することが必要である。

まず, 水量については, 降雨に伴う水量変化を浸出水 調整池の容量と水処理施設の多系列化・多層化によって 吸収することであり，短期の変化は主に前者によって， 季節的変化は後者によって解消する。そのため, 調整池 容量と水処理能力を同時に合理的に決定することが重要 である。

アンケートから水処理施設の処理能力や調整池の実態 を検討する。図 2,3 に計画平均水処理能力 $q_{a r}$

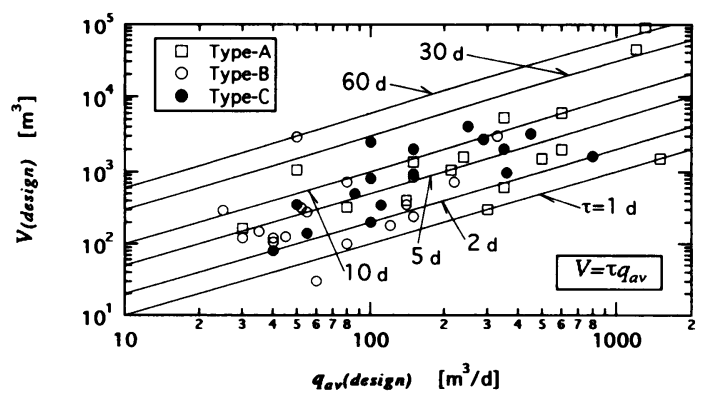

図 2 計画平均水処理能力 $q_{a !}$ 之調整池容量 $V$ の関係

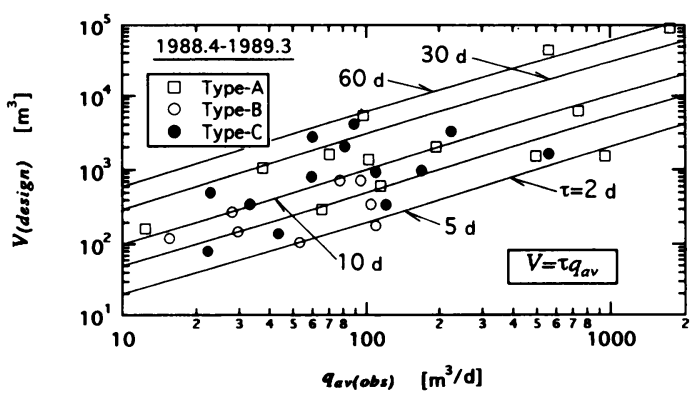

図 3 年間平均浸出水量 $[1988$ 年度 $] q_{a v}$ 之調整池容 量 $V$ 関係 


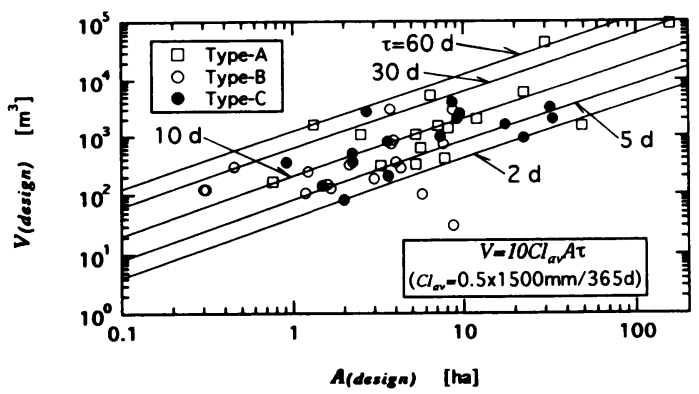

図 4 計画集水面積 $A$ 之調整池容量 $V$ の関係

（design）及び年間平均浸出水量 $q_{a v}(o b s)$ [1988 年度 $]$ 対調整池容量 $V$ の関係，及び四 4 に集水面積（計画） $A$ 対 $V$ の関係を示す。四中の記号は, 集排水管の末端 にバルブ等がなく浸出水が自然流下により常時流出する 形態のもの（Type-A と記す） 16 力所, 平地埋立や埋 立地内ピット・ポンプアップ方式で浸出水の内部眝留を 前提にしているすの（Type-B）18 力所, 浸出水が自然 流下する形態であるが末端にバルブ等があり浸出水の内 部眝留が可能なもの（Type-C）16 力所に分類して示し たものである。困中に調整池の平均滞留時間 $\tau$ を計算に より求め示したが, 現状としては, てに大きな幅があり, 明確な決定基準がないことが分かる。なお, 発生水量が 計画処理水量より小さい傾向にあるので, 実態としては より大きなてとなっていることが図 3 からあ分かる。

指針解説では浸出水は速やかに埋立層外に集排水する ことが原則である。浸出水の埋立地内眝留には触れてい ないが，例示的に「埋立地の使用期間が 10 年の場合, 年間降雨量が 10 年に 1 回の発生確率となる年の日降水 量時系列を用いて（調整池容量と水処理能力を決定す る）のも1つの考え方であろう」（指針解説 p. 123）と 述へ，その場合それ以上の降雨に対しては浸出水を内部 に眝留せざるを得ないことを暗に示している。しかし， 余りにむ小さなてを設計時に設定しているというのは内 部眝留を前提とした設計であり，指針解説の認めないと ころである。準好気性埋立の考え方に立つならば大きな 調整池は必然である（ほとんどの施設で大きな洪水調整 池は計画されるのに, 浸出水調整池が計画されないのは 奇異に感じる)。筆者はある計算事例 ${ }^{5}$ から, 最大処理 能力が平均降水量の 2 倍であるケースでは調整池容量と しては平均浸出水量の 40 日分 $(\tau=40 \mathrm{~d})$ が必要であ るという計算を示している。

次に, 集水面積（計画） $A$ 対計画平均水処理能力 $q_{a v}$ (design) 及び年間平均浸出水量 $q_{a v}(o b s)$ の関係を図 5,6 に, 年間平均浸出水量 $q_{a v}(o b s)$ [1988 年度] 対 $q_{a v}($ design $)$ の関係を図 7 に示す。図 5 から, 水処理能 力設計值は, わが国で考えられる平均的な值 $C I_{a v}=0.5$

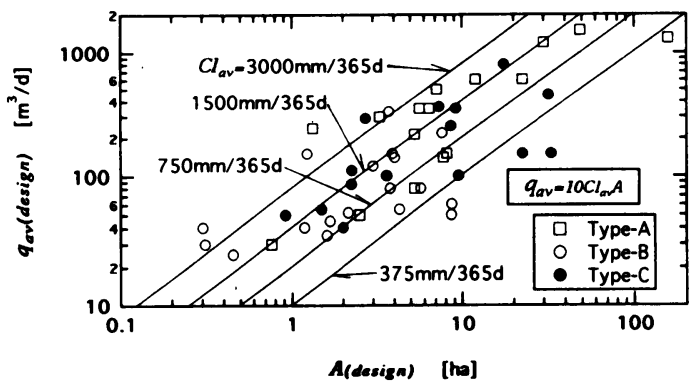

図 5 計画集水面積 $A$ 之計画平均水処理能力 $q_{a v}$ の関係

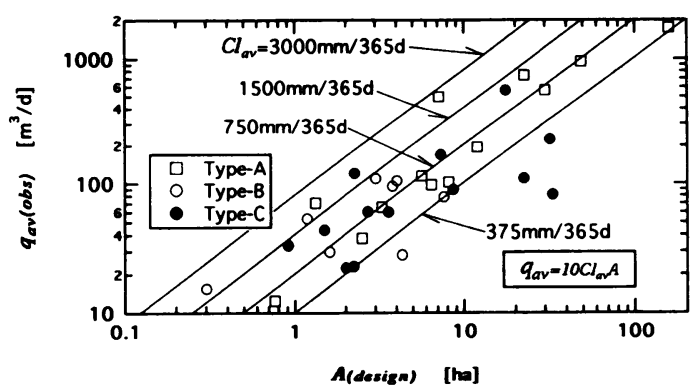

図 6 計画集水面積 $A$ と年間平均浸出水量 [1988年度 $]$ $q_{a v}$ の関係

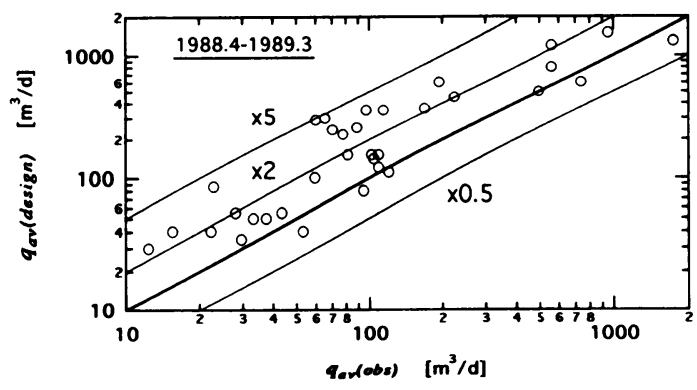

図 7 年間平均浸出水量 $[1988$ 年度 $] q_{a v}$ 之計画平均 水処理能力 $q_{a v}$ の関係

$\times 1500 \mathrm{~mm} / 365 \mathrm{~d}$ で計算される値より大きな値を中心に 分布し,また図 6 から実際の平均浸出水量は平均的な $C I_{a v}=0.5 \times 1500 \mathrm{~mm} / 365 \mathrm{~d}$ を中心に分布している。両 図とも $q_{a v}$ のばらつきは大きい。さらに図 7 から水処理 計画水量は実際の浸出水量の $2 \sim 5$ 倍にある。これは指 針解説でも述べているように（p. 128）, 「水処理能力を 浸出水調整設備の水量調整対策を勘案し, 平均浸出水量 と最大浸出水量の間で設定する」ことから, 平均浸出水 量より大きくなって当然である。

今後, 水処理施設の多系列化や多重化技術を開発する と共に, 計画平均水処理能力を平均浸出水量の何倍程度 に設定して調整池容量をどの程度の値に設定すればよい かについて研究する必要がある。 


\section{6. 漫出水質と水処理施設の設備}

埋立地浸出水の水質の事前予測は大变に難しい。その 理由は, 埋立作業の違いや埋立地内の環境条件の違いに より水質が大きく変化するからであり, 併せてそれに関 する研究が遅れているために何が基本的要因であるか不 明であるからである。一方, ごみ質が従来の混合ごみ主 体から焼却灰や不燃ごみ主体の埋立地に変化しつつある ために経験の蓄積が不十分であることも指摘できる。焼 却灰のみの埋立地も出現し, 種々の問題が生じている。 また, 有機污濁についてみると埋立開始当初は易生分解 性有機物の多い排水であるが時間の経過と共に難生分解 性のものに変化していくことも水処理施設の設備構成が 複雑化せざるを得ない要因の一つとなっている。

アンケートから，放流水基準を定め水処理の対象とし ている項目にっいて見る（重金属項目を除く）と, $\mathrm{pH}$, $\mathrm{BOD}, \mathrm{SS}$ ，大腸菌群数を処理対象としているすの 6 力 所, さらにCODを加えているもの13 力所, さらに窒 素を加えているもの 26 力所，さらに色度または $\mathrm{Ca}$ を くわえているあの 7 力所, 下水道などへ放流するすの 5 力所, 不明 7 力所であり, 砂滤過を設備するものは 42 力所中 35 力所, 活性炭吸着塔を設備するむのは 42 力所 中 24 力所あった（他の施設は不明）。また, BOD, $\mathrm{COD}, \mathrm{T}-\mathrm{N}$ について流入水質（計画）と1988 年度の测 定值（年間 12 回の測定を行っているものが多い，また， 浸出水か処理原水か明確でない）の最大值の関係を図 8 に示した。一部で計画値を超えた水質が発生しているが, この程度であれば水処理可能であると思われる。むしろ， 計画値の $1 / 10 \sim 1 / 100$ に低下しているものも見られ, この点に水質の事前予測や水処理操作の難しさがあると 思われる。具体的には, 実測最大值と計画値の比が 1 よ り大きなものが, $\mathrm{BOD} ; 2, \mathrm{COD} ; 1, \mathrm{~T}-\mathrm{N} ; 1$ 力所, $1 \sim 0.5$ のものが BOD; $1, \mathrm{COD} ; 1, \mathrm{~T}-\mathrm{N} ; 3,0.5$ 〜 0.1 のものが BOD; $3, \mathrm{COD} ; 6, \mathrm{~T}-\mathrm{N} ; 2,0.1 \sim$ 0.01 のものが $\mathrm{BOD} ; 5, \mathrm{COD} ; 3, \mathrm{~T}-\mathrm{N} ; 0$ 力所であり,

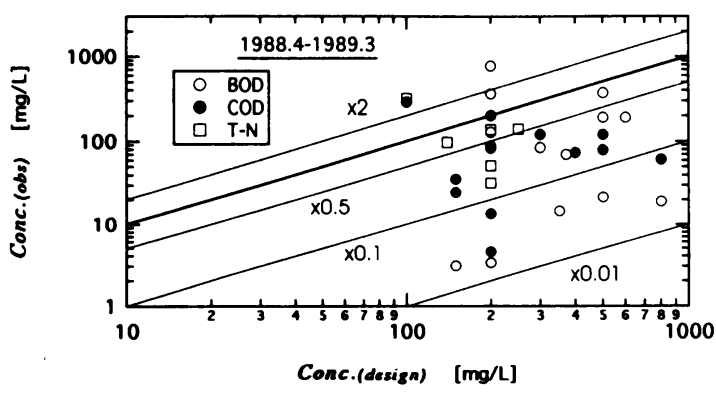

図 8 計画流入水質値と浸出水質（妈理原水水質）測 定檤（年間最大値;1988年度）の関係

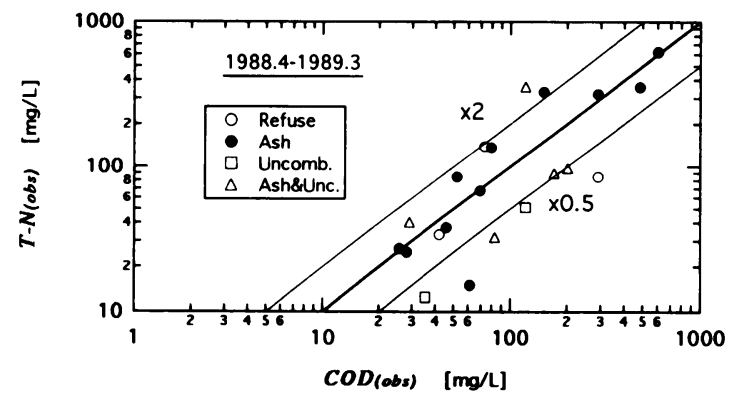

図 9 浸出水質（処理原水水質）の C O L と B O D の 関係

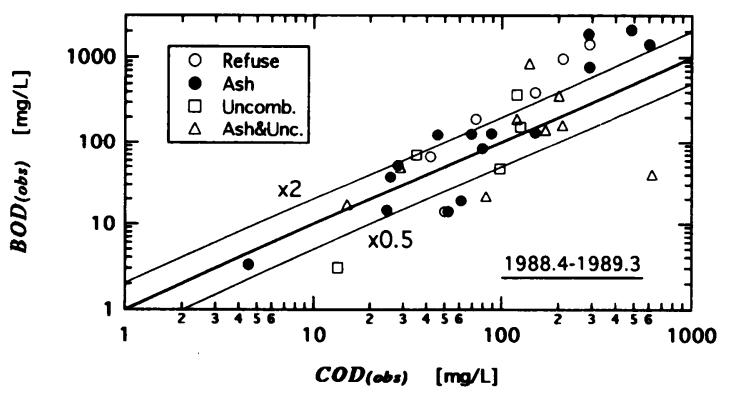

図10 浸出水質（処理原水水質）のＣＯとと T - N の 関係

BOD で実測值が計画値よりも極端に低下している事例 が多くみられるが， T-Nでは少ない（ほとんどの施設 で T-N の大部分は $\mathrm{NH}_{4}-\mathrm{N}$ であった）という傾向が見 られる。

次に, BOD, COD, T-N の実測値の相関関係を図 9 , 10 に示した。戍中の記号は，埋立ごみに混合ごみまた は可燃ごみが 2 割以上含まれているもの（Refuse と記 す), 7 割以上が焼却残渣であるもの (Ash), 7 割以上 が不燃ごみであるもの (Uncomb.)，焼却残渣と不燃ご みの埋立であるもの（Ash \& Unc.）に分類して示し た。

図 10 から, BOD と COD の関係では高濃度側で $\mathrm{BOD}>\mathrm{COD}$ であり，低濃度側で $\mathrm{BOD}<\mathrm{COD}$ の傾向が 見られる。これは埋立初期で易生分解性であった有機励 濁が時間の経過之共に難生分解性のものに変化すること を反映している。また，高濃度になったものを精查する 之, 焼却残渣埋立地 4 例の内, 2 例は改良型衛生埋立. と 回答し，1例はし尿污泥を少量投入し，残る1例は内部 眝留のあった施設である。また，焼却残渣と不燃ごみの 埋文地での 1 例も内部貯留のあった施設である。また, 威 9 から COD と T-N はほぼ似た值を示すことが, 特 に焼却残渣埋立地で見られることは興味深い。今後とも このような経験情報を蓄積し，より合理的な施設設計を 行えるようにすることが重要である。 


\section{7.おわりに}

指針解説の刊行された時期における埋立地施設の状況 を, 指針解説の意図, 特に浸出水の迅速排出之準好気性 埋立機能の増進という観点から検討した。当然のことか あ知れないが，指針解説のこの意図はまだ十分に理解さ れ，実行されているとはいえない。恐らく，これから設 計計画される施設においてもこの意罒が理解され実行さ れるか危俱される。その理由の一つは, 埋立地用地の確 保難から大容量の浸出水調整池を設けることが困難とさ れていることにある。そのため, 浸出水の埋立地内眝留 が前提となり，このことが污水の地下漏出のリスクを増 加させ, 準好気性構造の機能を阻害している。しかし， 洪水調整池は確保されている場合は多く, 決して浸出水 調整池の確保が難しいのではなく，浸出水の迅速集排水 の概念が十分に理解されていないことにあるのではない かと思われる（浸出水調整池の合理的な決定基準が明確 にされていないことにあ一因がある）。今後とも，市町 村やコンサルタントなどの関係者の一層の努力を期待し たい。

\section{引用文献}

1）全国都市清掃会議発行、厚生省水道環境部監修：「廃 棄物最終処分場指針解説」(1990)

2 ）厚生省生活衛生局水道環境部：「最終処分場の管理技 術に関する調查報告書」(1988)

3) 田中信寿他：土木学会第 45 回年次学術講演会講演要旨 集（第 II 部)，pp. 976-977，984-985，986-987（1990）

T. Matsuto, N. Tanaka and K. Koyama: "Stabilization mechanism of leachate from semiaerobic sanitary landfills of organic-rich waste", Proceedings Sardinia 91, Third International Landfill Symposium, pp. 875-888 (1991)

4 ）本南勲, 楠田哲也, 花嶋正孝, 島岡隆行 : 埋立廃棄物 層内における水質・水分分布特性に関する研究，第 1 回廃棄物学会研究発表会講演論文集, pp. $361-364$ (1990)

5 ）田中信寿他：廃裹物埋立地浸出水量推定及び処理施設 容量决定に関する理論的考察，都市と廃衰物，第 12 巻、 第 10 号, pp. $25-34$, 第 11 号, pp. $43-54$, 第 12 号, pp. $15-21$ (1982)

\title{
Quantity and Quality Issues on Landfill Leachate and the Function of Semi-Aerobic Landfill
}

\author{
Nobutoshi TanAKa \\ Professor of Hokkaido University \\ (Nishi 8 chome, Kita 13jo, Kita-ku, Sapporo, Hokkaido 060 Japan)
}

\begin{abstract}
Control of leachate in sanitary landfills presents a difficult problem. In Japan, the primary technique for leachate control is to quickly collect and drain all the leachate from landfill layer, and to let air flow steadily into the landfill layer. The technique can be carried out by designing reasonable leachate collectionpipe lines and a leachate adjustment pond.

Dimensions and structure of the equipments were discussed on the basis of our inquiry to nationwide municipalities. Then, I pointed out that it is important to propagate the concept of semi-aerobic landfill more and more, and to develop a decision-making method of arrangement and dimensions of the pipelines as well as capacity of the adjustment pond.
\end{abstract}

Key words : leachate quantity, leachate quality, semi-aerobic, leachate adjustment pond, leachate collection and drainage pipes 